\title{
Determination of the Behaviour and the Transport Parameters of Chromium in Soil-Water Systems
}

\author{
${ }^{1}$ I. CZINKOTA, ${ }^{1}$ I. ISSA, ${ }^{1}$ G. RÉTHÁTI and ${ }^{2}$ B. KOVÁCS \\ ${ }^{1}$ Szent István University, Gödöllő, and \\ ${ }^{2}$ University of Szeged, Szeged (Hungary)
}

\begin{abstract}
Chromium(VI) is toxic to biological systems due to its strong oxidizing potential that can damage cells. Total chromium in natural soils ranges from 1 to $3000 \mathrm{mg} / \mathrm{kg}$, with a typical concentration around $53 \mathrm{mg} / \mathrm{kg}$ (RICHARD \& BOURG, 1991). The natural total chromium content of surface waters is approximately $0.5-2 \mu \mathrm{g} / 1$ and the dissolved chromium content is $0.02-0.3 \mu \mathrm{g} / \mathrm{l}$. Chromium concentrations in Antarctic lakes increase with depth from $<0.6$ to $30 \mu \mathrm{g} / \mathrm{l}$. Most surface waters contain chromium in amounts between 1 and $10 \mu \mathrm{g} / \mathrm{l}$. In general, the chromium content of surface waters reflects the extent of industrial activity (WHO, 1996). Chromium is widely distributed in the earth's crust. It is present in oxidation states of +2 to +6 . Soils and rocks may contain small amounts of chromium, almost always in the trivalent state. Many techniques are used for the determination of total chromium, including atomic absorption spectroscopy, emission spectroscopy, X-ray fluorescence, and neutron activation analysis. Detection limits for atomic absorption spectroscopy are in the range of 0.05 to $0.2 \mathrm{~g} / \mathrm{l}$. The distribution of compounds containing chromium(III) and chromium(VI) depends on the redox potential, the $\mathrm{pH}$, the presence of oxidizing or reducing compounds, the kinetics of the redox reactions, the formation of chromium(III) complexes or insoluble chromium(III) salts, and the total chromium concentration. In the environment chromium(VI) occurs mostly as $\mathrm{CrO}_{4}{ }^{2-}$ or $\mathrm{HCrO}_{4}{ }^{-}$and chromium(III) as $\mathrm{Cr}(\mathrm{OH}) \mathrm{n}(3-\mathrm{n})^{+}$. The fate of chromium entering the environment depends on the $\mathrm{pH}$ and redox potential of the site. $\mathrm{Cr}^{\mathrm{III}}$ and $\mathrm{Cr}^{\mathrm{VI}}$ are stable in the $\mathrm{pH}-\mathrm{E}_{\mathrm{h}}$ range of most natural environments. In the normal $\mathrm{pH}$ range of 4 to 9 , chromium appears as insoluble $\mathrm{Cr}^{\mathrm{III}}$ in more reducing environments, versus more soluble $\mathrm{Cr}^{\mathrm{VI}}$ forms (including chromate and dichromate) in oxidizing environments (KOTAS \& STASICKA, 2000). Various inorganic compounds affect the fate of chromium in the environment. Chromium(VI) has been shown to be reduced by $\mathrm{Mn}^{\mathrm{II}}$ to $\mathrm{Cr}^{\mathrm{III}}$, while colloidal $\mathrm{MnO}_{2}$ oxidized $\mathrm{Cr}^{\mathrm{III}}$ to $\mathrm{Cr}^{\mathrm{VI}}$ (PEREZ-BENITO \& ARIAS, 2001).

Chromium mobility and bioavailability in soils and natural waters are linked to transfers of electrons between this metal and other constituents in these environ-
\end{abstract}

Correspondence to: IMRE CZINKOTA, Szent István University, Department of Soil Science and Agricultural Chemistry, H-2103 Gödöllö, Páter K. út 1. Hungary. E-mail: imre.czinkota@gmail.com 
ments, where biological and chemical processes control oxidation and reduction reactions. Gains of electrons (reduction) by electron-poor, hexavalent chromium $\left(\mathrm{Cr}^{\mathrm{VI}}\right)$ convert this toxic, soluble anion [negatively-charged species, e.g. $\mathrm{CrO}_{4}{ }^{2-}$ ] to electron-rich, trivalent chromium $\left(\mathrm{Cr}^{\mathrm{III}}\right)$, a form that is non-toxic, essential for human health, cationic (positively-charged, e.g. $\mathrm{Cr}^{\mathrm{III}+}$ ), and only sparingly-soluble in most natural environments (BRUCE \& JAMES, 2002)

One of the treatment strategies for chromium contaminated soil and groundwater is to reduce soluble $\mathrm{Cr}^{\mathrm{VI}}$ to insoluble $\mathrm{Cr}^{\mathrm{III}}$ either ex situ or in situ. Taking advantage of microbial activity for reducing $\mathrm{Cr}^{\mathrm{VI}}$ is probable to be cost effective and environment-friendly. Natural microbes of many genera - including Bacillus, Enterobacter, Escherichia, and Pseudomonas - have been reported to enzymatically reduce $\mathrm{Cr}^{\mathrm{VI}}$ to $\mathrm{Cr}^{\text {III }}$ (PHILIP et al., 1998).

Natural soil environments are characterized by $\mathrm{pH}$ values from approximately 3 to 10 and by oxidation-reduction potentials $\left(\mathrm{E}_{\mathrm{h}}\right)$ ranging from -300 to $+1000 \mathrm{mV}$, depending on $\mathrm{pH}$. The speciation, solubility, mobility and bioavailability of chromium are all influenced by $\mathrm{pH}$ and $\mathrm{E}_{\mathrm{h}}$ as master variables controlling chemical reactions and biological activity. Therefore, relevant environmental conditions chosen to study and predict the behaviour of $\mathrm{Cr}$ in soils may cover a wide range in acidity, redox status, organic matter content, clay content and other properties (BRADY \& WEIL, 2002).

The study aimed to evaluate the effect of $\mathrm{pH}$ and $\mathrm{E}_{\mathrm{h}}$ changes on chromium in a floodplain, where the flows of the river change the redox potential to a great extent as a result of the low redox buffering capacity of the soil. The investigation was performed in two stages. In the first phase a theoretical chemical equilibrium calculation was carried out to evaluate the solubility of chromium as a function of different soil properties. In the second stage the laboratory experiment for determining contaminant transport parameters was performed. Both investigations served the evaluation of the environmental risk of a given pollution.

\section{Material and Modelling Methods}

The investigated soil - sandy gravelly silt textured, originating from the alluvial deposits of the Danube River - has a humus content less than $0.5 \%$, a very low colloid content, and high hydraulic conductivity. The investigated soil is the single protective soil layer above the groundwater, which is the reason why its multipurpose investigation was required.

The modelling was performed using geochemical equilibrium models developed by EPA that calculate values on the basis of physico-chemical equilibriums. The database of the program contains the equilibrium parameters of practically all perceivable inorganic substances in solution or precipitation form. From these data it calculates the parameters of the ingredients present in the given case with iteration (Table 1).

During the iteration process the aggregation of the over-saturated solutions was allowed, therefore the concentration of the solutions that originally had a higher 
Table 1

The initial parameters for the soil originating from the alluvial deposit of the Danube River

\begin{tabular}{|l|l|l||l|l|l|}
\hline Parameter & Value & Unit & Parameter & Value & Unit \\
\hline $\mathrm{Ca}^{2+}$ & 0.01 & $\mathrm{~mol} / \mathrm{l}$ & $\mathrm{Fe}^{3+}$ & 0.0001 & $\mathrm{~mol} / \mathrm{l}$ \\
$\mathrm{CO}_{2}$ & 0.00035 & $\mathrm{Bar}$ & $\mathrm{pH}$ & $7.4(6.8-7.7)$ & - \\
$\mathrm{Cr}(\mathrm{OH})^{2+}$ & 0.0001 & $\mathrm{~mol} / 1$ & $\mathrm{Mn}^{2+}$ & 0.0001 & $\mathrm{~mol} / \mathrm{l}$ \\
$\mathrm{CrO}_{4}{ }^{2-}$ & 0.0001 & $\mathrm{~mol} / \mathrm{l}$ & $\mathrm{Mn}^{3+}$ & 0.0001 & $\mathrm{~mol} / \mathrm{l}$ \\
$\mathrm{E}_{\mathrm{h}}$ & $430(360-500)$ & $\mathrm{mV}$ & $\mathrm{PO}_{4}{ }^{2-}$ & 0.0001 & $\mathrm{~mol} / \mathrm{l}$ \\
$\mathrm{Fe}^{2+}$ & 0.0001 & $\mathrm{~mol} / 1$ & $\mathrm{SO}_{4}{ }^{2-}$ & 0.01 & $\mathrm{~mol} / \mathrm{l}$ \\
\hline
\end{tabular}

concentration than the measured value decreased to equilibrium values. The models were run with different combinations of parameters in order to be able to determine the effect the alterations of $\mathrm{pH}$ and $\mathrm{E}_{\mathrm{h}}$ had on the soluble chromium content of the water. The following redox reactions were enabled: $\mathrm{Cr}^{\mathrm{III}} / \mathrm{Cr}^{\mathrm{VI}}, \mathrm{Fe}^{\mathrm{II}} / \mathrm{Fe}^{\mathrm{III}}$ and $\mathrm{Mn}^{\text {II }} / \mathrm{Mn}^{\text {III }}$, each having a value of $0.0001 \mathrm{~mol} / \mathrm{l}$.

Methodology. - A program was created that changed the input file of MINTEQ, based on the change of the variables. Consequently, MINTEQ was run, and the essential concentration values were collected from the results file. These served as a basis for drawing the concentration curves. For a better understanding a threedimensional plot was made by Surfer software, based on the calculated database.

\section{Results and Discussion of Modelling}

Effect of the redox potential on the $\mathrm{Cr}^{V I}$ concentration in soil solution

The analysis was conducted at a given $\mathrm{pH}$ value and the model was run several times with the alteration of the $\mathrm{E}_{\mathrm{h}}$ values. The analyzed $\mathrm{pH}$ value was 7.4 and the $\mathrm{E}_{\mathrm{h}}$ value was altered between 340 and $500 \mathrm{mV}$, with steps of $20 \mathrm{mV}$. In Fig. 1 the logarithm of the balance concentration of chromium-containing forms with an oxidation state of VI is demonstrated

The $\mathrm{CrO}_{4}{ }^{2-}$ ion concentration is the highest, the concentration of other ions changes the complete $\mathrm{Cr}^{\mathrm{VI}}$ concentration by maximum $10 \%$. With the enhancement of the redox potential the logarithm of the concentration of chromium with an oxidation grade of 6 increases linearly in the $360-460 \mathrm{mV}$ domain, it stagnates in the $480 \mathrm{mV}$ domain, and above this, it increases again in the original rhythm. There is a two-fold rise in the logarithmic change of concentration of the $\mathrm{Cr}_{2} \mathrm{O}_{7}{ }^{2-}$ curve as compared to other components, however, its concentration is respectively smaller in the analyzed domain. The concentration of $10 \mu \mathrm{g} \cdot 1^{-1}$ (shown in the Figure) belongs to the pollution limit value in Hungary.

The presented three-dimensional summary (Fig. 2) shows all the information mentioned above. It represents the solubility of chromium as the function of redox and $\mathrm{pH}$ values. It can be observed that the chromium concentration reaches its peak in the case of $\mathrm{pH}$ higher than 8 and medium redox potential of 550, which means it 


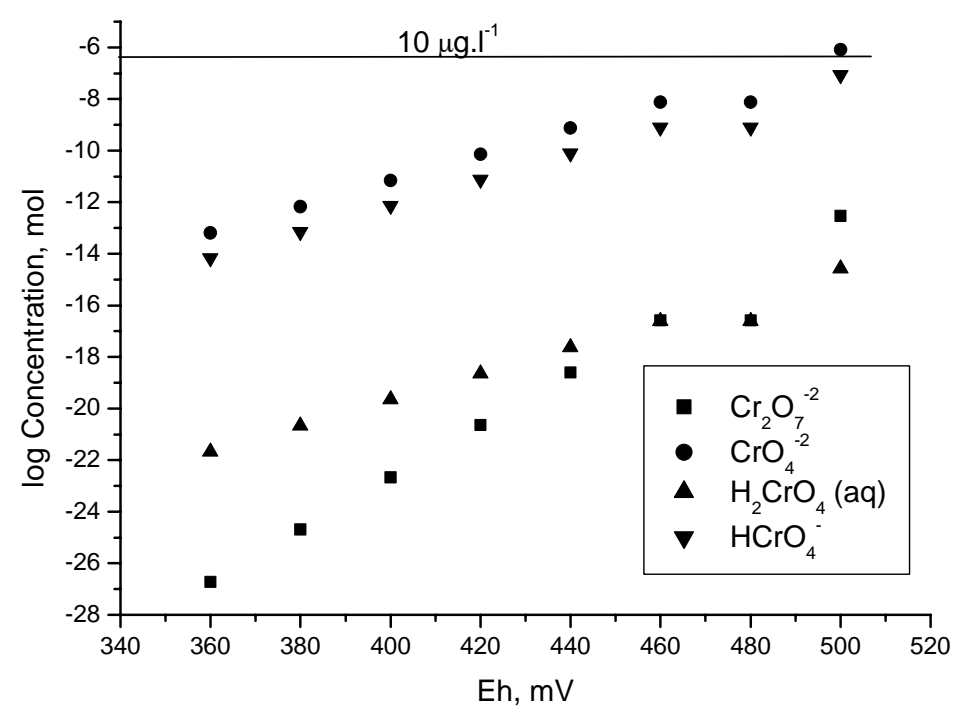

Fig. 1

The logarithm of the balance concentration of different $\mathrm{Cr}^{\mathrm{VI}}$ species as a function of the redox potential $\left(\mathrm{E}_{\mathrm{h}}\right)$ at $\mathrm{pH}$ 7.4. Remark: $10 \mu \mathrm{g} \cdot \mathrm{l}^{-1}=$ chromium pollution limit value in Hungary

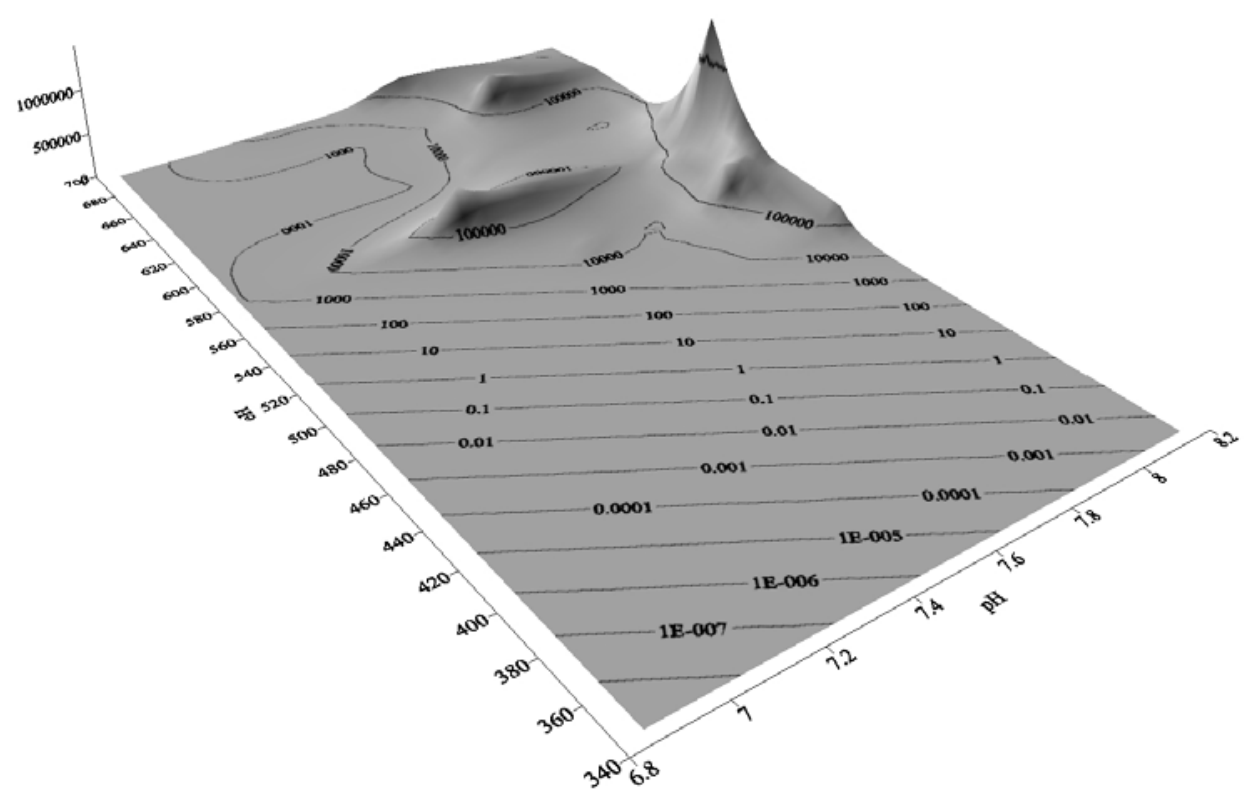

Fig. 2

Different $\mathrm{Cr}^{\mathrm{VI}}$ species as the function of $\mathrm{pH}$ and redox potential $\left(\mathrm{E}_{\mathrm{h}}, \mathrm{mV}\right)$ 
reaches the level of pollution not only if the redox potential value is as high as 750 $\mathrm{mV}$. From the examined $\mathrm{pH}$ values higher chromium concentration was registered at around $\mathrm{pH} 7.6$ and redox potential value of $550 \mathrm{mV}$.

The changes in $\mathrm{pH}$ are due to the oxidative-reductive actions resulting from temporary floods. Change in acidity affects the concentration of soluble chromium species. The model shows a non-linear correlation, and at certain specific points the concentration of the contaminating substance increases sharply.

\section{Methodology of Laboratory Determination of Chromate Transport Parameters}

The studied soil - the protective soil layer above the groundwater - was later investigated using a numerical contaminant transport model. For determining the input parameters of the numerical simulations a laboratory experiment with a special curve fitting evaluation method was used.

The determination of transport parameters was performed in a flexible wall permeameter using undisturbed soil samples. The equipment is capable of determining the hydraulic permeability of the sample during the experiment, but it was also useful for calculating the transport parameters and chromate retention capacity of the sample. The $2-3 \mathrm{~cm}$ thick samples were formed and built into the triaxial cell. A filter was installed both below and above the sample to avoid grain outwash from the sample. The sample's sidewall was covered with a membrane that was pressed to the sample using a 0.1 bar higher pressure than the test fluid's pressure. During the test distilled water was used until the sample became fully saturated and up to reaching the steady-state migration through the sample, at $\mathrm{I}=30$ hydraulic gradient. Hydraulic conductivity was calculated from the water volume that migrated through the sample, using the constant head principle. After that phase the test fluid was changed to another fluid with 200 ppm chromate ion content. The effluent solution was then collected and analyzed, and the breakthrough curves were determined.

The evaluation of the results was performed using the curve fitting method. Considering the $1 \mathrm{D}$ transport equation in the following form:

$$
R \cdot \frac{\partial c}{\partial t}=D \cdot \frac{\partial^{2} c}{\partial z^{2}}-v \cdot \frac{\partial c}{\partial z}
$$

with the below described initial and boundary conditions:

$$
\begin{array}{ll}
c(z, t)_{t=0}=0 & z \in[0, \infty) \\
c(z, t)_{z=0}=c_{0} & t>0 \\
\frac{\partial c}{\partial z} z_{z \rightarrow \infty}=0 & t>0
\end{array}
$$

the analytical solution (OGATA \&BANKS, 1961) could be derived:

$$
c=c_{0} \cdot\left[\frac{1}{2} \cdot \operatorname{erfc}\left(\frac{R \cdot z-v \cdot t}{2 \cdot \sqrt{D \cdot R \cdot t}}\right)+\frac{1}{2} e^{\frac{u \cdot z}{D}} \cdot \operatorname{erfc}\left(\frac{R \cdot z+v \cdot t}{2 \cdot \sqrt{D \cdot R \cdot t}}\right)\right]
$$


where: $c$ is the concentration, $c_{0}$ is the concentration of the influent solution, $R$ is the retardation factor, $D$ is the effective dispersion coefficient, $v$ is the seepage velocity, $t$ is the time and $\mathrm{z}$ is the distance along the axis.

For the curve fitting the following transformations were used:

$$
t=\frac{x}{v} \quad v \cdot t=x
$$

where: $x$ is the volume of effluent fluid.

The transport equation after transformation:

$$
c=\frac{c_{0}}{2} \cdot\left\{\left[1-\operatorname{erf}\left(\frac{R \cdot z-\frac{x}{A}}{2 \cdot \sqrt{D \cdot R \cdot \frac{x}{A \cdot v}}}\right)\right]+e^{\frac{v \cdot z}{D}} \cdot\left[1-\operatorname{erf}\left(\frac{R \cdot z+\frac{x}{A}}{2 \cdot \sqrt{D \cdot R \cdot \frac{x}{A \cdot v}}}\right]\right]\right\}
$$

\section{Results of the Laboratory Determination of Chromate Transport Parameters}

Using the curve fitting both the dispersion coefficient and the retardation factor were calculated (Table 2).

The measured breakthrough curves are shown in Fig. 3.

The advantage of this method is that the accuracy of the derived parameters is determined by means of the fitting error. As the device is used parallel to the determination of hydraulic conductivity and seepage velocity, there are no errors regarding the mentioned parameters. That increases the overall accuracy of the method in comparison to other column study methods. By repeating the measurement with different hydraulic gradients the dispersivity vs. seepage velocity function can be drawn as well.

The relatively high fitting errors highlight the potential doubtfulness of numerical transport modelling. Because of this a very conservative approach (worst case scenario) was always used during the numerical simulations.

Table 2

The values of fitted parameters for sample H6

\begin{tabular}{|l|l|c|c|c|c|c|c|}
\hline & $\begin{array}{c}\text { Retardation } \\
\text { faktor } \\
\mathrm{R}\end{array}$ & $\begin{array}{c}\text { Dispersion } \\
\text { constant } \\
\mathrm{D}^{*} \\
\mathrm{~cm}^{2} \cdot \mathrm{s}^{-1}\end{array}$ & $\begin{array}{c}\text { Concent- } \\
\text { ration } \\
\mathrm{c} \\
\mathrm{mg} \cdot \mathrm{dm}^{-3}\end{array}$ & $\begin{array}{c}\text { Speed } \\
\mathrm{v} \\
\mathrm{cm}^{3} \cdot \mathrm{s}^{-1}\end{array}$ & $\begin{array}{c}\text { Height } \\
\mathrm{cm}\end{array}$ & $\begin{array}{c}\text { Cross- } \\
\text { section } \\
\mathrm{A} \\
\mathrm{cm}^{-2}\end{array}$ & $\begin{array}{c}\text { Correlation } \\
\text { coefficient } \\
\mathrm{R}^{2}\end{array}$ \\
\hline Value & 5.84 & $\begin{array}{c}0.00024 \\
\text { Error }\end{array}$ & $\begin{array}{c}154.0 \\
2.67\end{array}$ & $\begin{array}{c}0.081 \\
\text { No fit }\end{array}$ & $\begin{array}{c}1.95 \\
\text { No fit }\end{array}$ & $\begin{array}{c}20 \\
\text { No fit }\end{array}$ & $\begin{array}{c}0.94 \\
\text { No fit }\end{array}$ \\
\hline
\end{tabular}




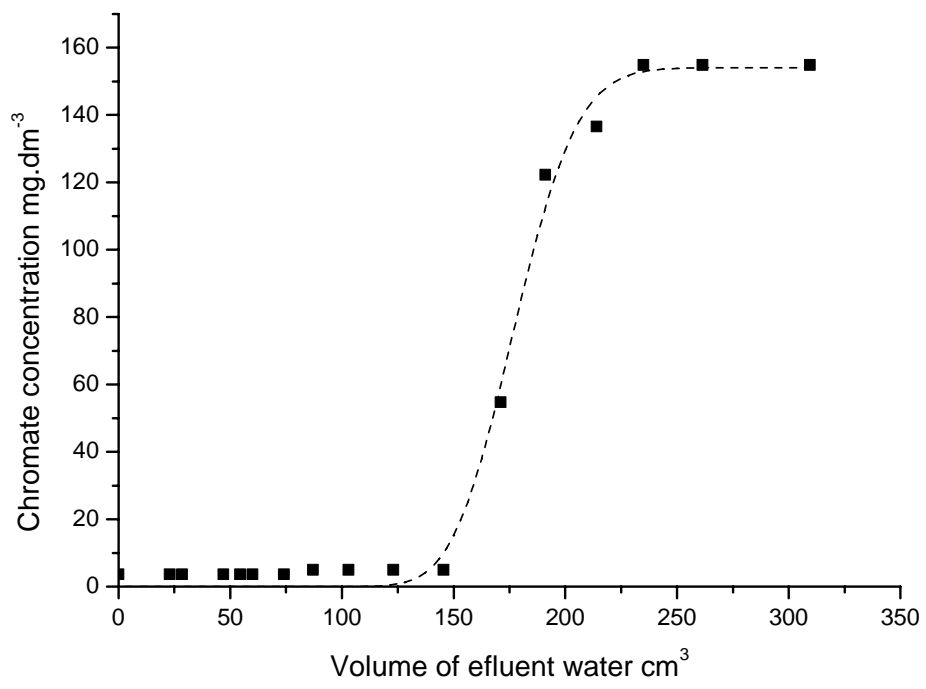

Fig. 3

Breakthrough curves measured for the determination of the chromate transport parameter

\section{Summary}

A complex investigation was performed for a polluted area using both experimental and computer modelling methods. Among the experimental methods the adsorption and desorption isotherms were measured to estimate the concentration dependent equilibrium in the soil-groundwater system.

A new calculation method was worked out for determining the transport parameters from results of laboratory tests. Heavy metal solution was leached through a soil column continuously. The effluent fluidum was collected, and the heavy metal concentration of the collected fractions was measured by atomic absorption spectrophotometer.

As the result of the analytic process breakthrough curves were measured in laboratory scale. Due to the applied initial and boundary conditions the transport equation can be solved analytically. Using the OGATA and BANKS (1961) solution of the transport equation a new curve fitting method was introduced. After several transformations of the equation a theoretical function was fitted to the measured concentration vs. time and to the concentration vs. effluent volume data. The parameters of the fitted curve could be used as the dispersion and retardation parameters of a transport model.

The water chemistry of the system controls the rate of adsorption and desorption of metals to and from sediment. Adsorption removes the metal from the water column and stores the metal in the substrate. Desorption returns the metal to the water column, where recirculation and bioassimilation may occur. Metals are probably 
desorbed from the soil if the salt concentration of the water increases, and in case of some metals decreases with the redox potential and with $\mathrm{pH}$.

Parallel to determining the basic transport parameters of the system using the column study, the maximal equilibrium concentration of chromium-containing compounds with different oxidation states were calculated with the MINTEQ model with two variable functions ( $\mathrm{pH}$ and redox potential). As a result of the calculations a non-liner relation was established, as at specific points the maximal equilibrium concentration of chromium increases with a high gradient. This means that there are combinations of $\mathrm{pH}$ and redox potential values in the case of which chromium has a high solubility. It is advisable to avoid these points in the $\mathrm{pH}-\mathrm{E}_{\mathrm{h}}$ field if we want to stabilize the contaminant. This state is to be reached when the goal is the mobilization of the pollutant to make the soil cleaning process possible. With the introduced calculation method areas on the $\mathrm{pH}$-redox potential field (at high $\mathrm{pH}$ and $\mathrm{E}_{\mathrm{h}}$ values) are found in which the concentration of pollutants may reach a critical value. The introduced calculation method is quick and gives results accurate enough for a pilot test.

Key words: Chrome, model parameters, redox, transport of heavy metals

\section{References}

Brady, N. C. \& WeIL, R. R., 2002. The Nature and Properties of Soils. $13^{\text {th }}$ ed. Pentice-Hall. Upper Saddle River, NJ.

JAMES, B. R., 2002. Chemical Transformations of Chromium in Soils: Relevance to Mobility, Bio-availability and Remediation. ICDA Publications. No. 8. Paris.

Kotas, J. \& StasickA, Z., 2000. Chromium occurrence in the environment and methods of its speciation. Environ. Pollut. 107. 263-283.

OgatA, A. \& BANKS, R. B., 1961. A Solution of Differential Equation of Longitudinal Dispersion in Porous Media. U.S. Geological Survey Professional Paper 411-A. U.S. Government Printing Office. Washington, D. C.

Philip, L., IYenGaR, L. \& VenKobachar, C., 1998. $\mathrm{Cr}^{\mathrm{VI}}$ reduction by Bacillus coagulans isolated from contaminated soils. J. Environ. Eng. 124. 1165-1170.

Perez-Benito, J. F. \& ARIAS, C., 2001. The pyrophosphate-assisted reduction of chromium(VI) by manganese(II) and its reverse reaction. New J. Chem. 25. 1438-1446.

RichaRD, F. C. \& BOURG, A. C. M., 1991. Aqueous geochemistry of chromium: A review. Water Res. 25. 807-816.

World HEALth ORGANiZATION (WHO), 1996. Guidelines for Drinking Water Quality. $2^{\text {nd }}$ ed. Vol. 2. WHO. Geneva. 